\title{
Design of Attendance Recording System for Pilkades Participants Using Web-Based RFID (E-KTP)
}

\author{
Atmiasri \\ Department of Electrical Engineering \\ University of PGRI Adi Buana Surabaya \\ atmi.asri@yahoo.com
}

\begin{abstract}
The development of information technology has now been widely used to facilitate, accelerate, and streamline work. The recording system that is still being applied is a type of recording using a manual system using paper media and is inefficient when viewed from a time perspective, recapitulating attendance data and the accuracy or authenticity of the data presented. There is still a frequent habit of voting in the village head elections or not being present at the voting process. Contrary to these problems, this research has developed a recording system using RFID (Radio Frequency Identification) technology. RFID will use sensors to read data. The use of RFID which can make it easier for KPPS officers at TPS. The use of both active and passive RFID technology is able to help record and move data in KPPS, Use of RFID technology, data will be recorded only by passing through a sensor reader on the device, thus the attendance data present by pilkades participants will be stored automatically in storage. So that the attendance of election participants will be easier to do, faster and avoid human error or fraud in the absence of pilkades
\end{abstract}

Keywords: attendance, web, database, RFID

\section{INTRODUCTION}

The development of science and technology in the industrial era 4.0 is very influential in various human lives. This can be seen by the various facilities that are offered and provided. In connection with the development and sophistication of technology, creative and innovative human resources are needed to deal with this technological sophistication, thus no longer lagging behind the progress of other countries.

Election attendance data collection activities are routinely carried out. In general, this is done by signing the election attendance sheet. This is considered by the public to be slow and also creates interference in carrying out attendance in the election

\author{
Eko Andris Kosmono \\ Department of Electrical Engineering \\ University of PGRI Adi Buana Surabaya \\ ekoandris09@gmail.com
}

process. The solution to solve this problem will be research on the ability of contactless cards with an embedded RFID tag, for functional and nonfunctional needs required by the election attendance system. Contactless card-based election attendance systems have been widely used by various types of companies for employee attendance purposes. The problem is that there is no RFID card-based software that is able to meet the needs of election attendance systems at TPS (polling stations). Recording attendance of election participants is still done manually by filling in the attendance signature on the sheet. In addition, errors often occur when inputting attendance data by KPPS (Voting Organizing Group) officers. The solution to the problem is designing RFID smart card-based software that is able to meet the needs of the election attendance system at TPS. The results of this study are expected. produce a prototype RFID card-based attendance system that can be used as attendance for election participants. The purpose of this research is to describe the role In addition, errors often occur when inputting attendance data by KPPS (Voting Organizing Group) officers. The solution to the problem is designing RFID smart card-based software that is able to meet the needs of the election attendance system at TPS. The results of this study are expected. produce a prototype RFID card-based attendance system that can be used as attendance for election participants. The purpose of this research is to describe the role In addition, errors often occur when inputting attendance data by KPPS (Voting Organizing Group) officers. The solution to the problem is designing RFID smart card-based software that is able to meet the needs of the election attendance system at TPS. The results of this study are expected. produce a prototype RFID card-based attendance system that can be used as attendance for election participants. The purpose of this research is to describe the role

$R F I D$ as one of the information technologies used in various fields, Researching access to speed 


\section{BEST}

Journal of Applied Electrical \& Science Technology - University of PGRI Adi Buana Surabaya

p-ISSN 2715-2871

e-ISSN 2714-5247

and sensitivity to the election recording system using RFID (E-KTP). Among that there is a scope in the research, namely the attendance attendance ystem sensor for pilkades participants that is used, namely using the RFID sensor, the microcontroller used is the NodeMcu Esp8266 microcontroller, the attendance data sample for the attendance of pilkades participants is 20 people.

\section{METHODS}

This type of study is a qualitative assessment where The research method is used to examine the RFID attendance system (e-KTP) in web-based elections. The method used is that the author conducts a process of observing the ability of the attendance system that has been previously applied in the surrounding environment. The author also conducts thorough research on the capabilities of software commonly used for worker attendance. In-depth research on the specified process is also carried out in order to be in line with the implementation of the system. Research on the database and programming language used in conventional systems is also carried out carefully to ensure the implementation stage can run smoothly. The materials and components used for the assembly process are: Nodemcu ESP8266, RFID tag, RFID Reader, LCD, mini speaker, jumper cable and also DF Player Mp3.

The variables used in the analysis are the independent variables and the dependent variable. The first to be discussed is the independent variable, which is a variable that affects security that was previously changed by the researcher to determine the relationship between the observed or researched phenomena. In this study the independent variables include: Speed and Delay in reading E-KTP. And the reading with the E-KTP is different. Furthermore, the dependent variable is the factor that will be observed or observed and is used to determine the influence of the

independent variable, namely the factor that appears, does not appear or change according to what is made by the researcher. In this study the dependent variable is Output Display on a laptop using the Localhost Website, Analyzing speed in reading E-KTP, Analyzing Sensitivity in reading E-KTP.

\section{RESULTS AND DISCUSSION}

This RFID-based attendance system involves several actors who act as data sources, users, and parties who manage data pulled from attendance machines. The RFID Attendance System is an IoT project based on the esp 8266 microcontroller which is integrated with a simple php web and mysql database. The microcontroller device acts as a client that

communicates data with the server using the HTTP protocol where the client requests data which then the server responds in the form of JSON data



Fig. 1. RFID Attendance System Network Topography

\section{Database System Design}

The database used in this RFID-based presence system uses a database system that is managed on the Web. In this study, there are 2 databases created to store data, namely the resident attendance database and the citizen data database.

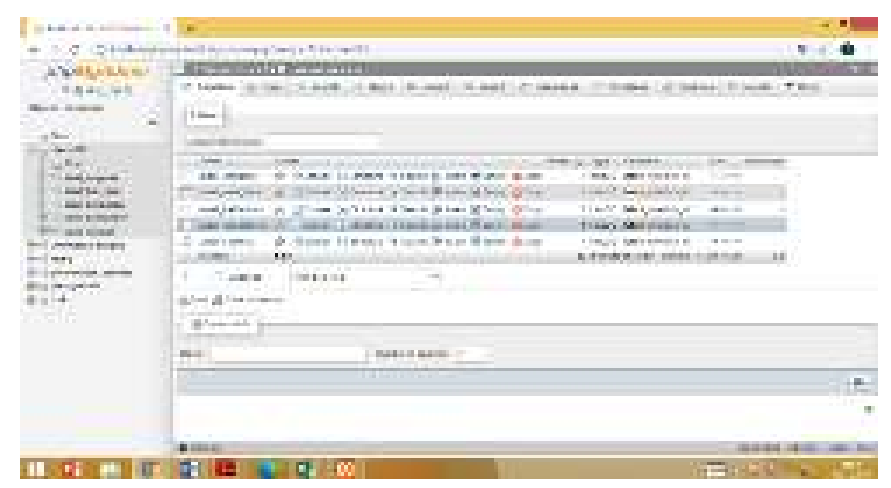

Fig. 2 Attendance Database

Citizen Attendance Database: This database functions to record data when residents do attendance. The data recorded in this database is in the form of RFID code and time attendance of residents.

Citizen data database: This database functions to store citizen data. Before you can do attendance. Table of test results for reading distance ID e-KTP ID reading distance testing is done manually using a ruler, this test is carried out for each e-KTP and measured from the outside of the box with a box thickness of $4 \mathrm{~mm}$. This test is carried out with a range of $1 \mathrm{~cm}$ starting from a point $0 \mathrm{~cm}$ outside the box to a distance of $5 \mathrm{~cm}$ from outside the box. 
BEST

Journal of Applied Electrical \& Science Technology - University of PGRI Adi Buana Surabaya

p-ISSN 2715-2871

e-ISSN 2714-5247

Table 1.The results of the e-KTP ID reading distance test

\begin{tabular}{|c|c|c|c|}
\hline No. & $\begin{array}{c}\text { Distance } \\
(\mathrm{cm})\end{array}$ & Speaker & Information \\
\hline 1 & $1 \mathrm{~cm}$ & Sound & Legible \\
\hline 2 & $2 \mathrm{~cm}$ & Sound & Legible \\
\hline 3 & $3 \mathrm{~cm}$ & Sound & Legible \\
\hline 4 & $4 \mathrm{~cm}$ & Sound & Legible \\
\hline 5 & $5 \mathrm{~cm}$ & No Sound & Can not be read \\
\hline
\end{tabular}

Results of testing the time to read ID e-KTP apart from the process of reading distance data on e-KTP, we also try to measure the length of time in reading the e-KTP data. In measuring the length of time to read this ID data using a stopwatch. The following results are shown in the table below:

Table 2.The test results for reading the ID e-KTP

\begin{tabular}{|c|c|c|c|}
\hline No. & Time (s) & Speaker & Information \\
\hline 1 & 0.706 & Sound & Legible \\
\hline 2 & 0.643 & Sound & Legible \\
\hline 3 & 0.677 & Sound & Legible \\
\hline 4 & 0.704 & Sound & Legible \\
\hline
\end{tabular}

In table 4.3 when testing the time to read the data, the results are around 0.643-0.7 per second of data reading time. In this test there is no comparison with the datasheet. From the data run, it can be concluded that the RFID Reader can read ID e-KTP data in less than 1 second.

The results of the experiment on reading the ID eKTP

The results of the ID reading experiment were carried out as many as 20 e-KTPs. ID reading tests were carried out using the Typing method which was carried out by means of e-KTPs affixed to available hardware or tools at the appropriate distance. The following is the reading of the ID e-KTP shown in the table below:

Table 3.The results of the experiment on reading the ID e-KTP

\begin{tabular}{|c|c|c|c|c|c|c|}
\hline \multirow{2}{*}{ No. } & \multirow{2}{*}{$\begin{array}{l}\text { No. } \\
\text { ID }\end{array}$} & \multirow{2}{*}{ Member's name } & \multirow{2}{*}{ Date } & \multicolumn{2}{|c|}{ Entry Hours } & \multirow{2}{*}{ Information } \\
\hline & & & & Sign in & Check In & \\
\hline 1 & 101 & EKO ANDRIS & 03 August 2020 & $8: 00: 00$ & $8: 06: 00$ & ATTEND \\
\hline 2 & 102 & M. ATHO A & 03 August 2020 & 8:00:00 & $8: 06: 09$ & ATTEND \\
\hline 3 & 103 & GUSTI RAY & 03 August 2020 & $8: 00: 00$ & $8: 07: 10$ & ATTEND \\
\hline 4 & 104 & ACH FAUZI & 03 August 2020 & 8:00:00 & 8:07:16 & ATTEND \\
\hline 5 & 105 & MOCH. THOYIB & 03 August 2020 & 8:00:00 & $8: 07: 45$ & ATTEND \\
\hline 6 & 106 & ANUGERAH P. & 03 August 2020 & $8: 00: 00$ & $8: 08: 10$ & ATTEND \\
\hline 7 & 107 & MOCH. YUSUF & 03 August 2020 & 8:00:00 & 8:09:09 & ATTEND \\
\hline 8 & 108 & M. YUZRIL E. & 03 August 2020 & $8: 00: 00$ & 8:09:27 & ATTEND \\
\hline 9 & 109 & M. RAMZANI & 03 August 2020 & $8: 00: 00$ & $8: 10: 18$ & ATTEND \\
\hline 10 & 110 & RUDI SETIAWA & 03 August 2020 & $8: 00: 00$ & $8: 10: 20$ & ATTEND \\
\hline 11 & 111 & ARIK RIYANTO & 03 August 2020 & 8:00:00 & $9: 10: 20$ & ATTEND \\
\hline 12 & 112 & HASBI JAYA K. & 03 August 2020 & $8: 00: 00$ & $9: 10: 30$ & ATTEND \\
\hline 13 & 113 & KURNIAWAN S. & 03 August 2020 & 8:00:00 & $9: 10: 40$ & ATTEND \\
\hline 14 & 114 & JOHN & 03 August 2020 & 8:00:00 & $9: 10: 50$ & ATTEND \\
\hline 15 & 115 & ASTUTIC & 03 August 2020 & 8:00:00 & $9: 11: 10$ & ATTEND \\
\hline 16 & 116 & ADMISSION & 03 August 2020 & 8:00:00 & $9: 11: 30$ & ATTEND \\
\hline 17 & 117 & M. SALIM & 03 August 2020 & $8: 00: 00$ & $9: 12: 10$ & ATTEND \\
\hline 18 & 118 & RISKA DWI S. & 03 August 2020 & $8: 00: 00$ & $9: 12: 30$ & ATTEND \\
\hline 19 & 119 & ANDIK OPRAS & 03 August 2020 & $8: 00: 00$ & $9: 13: 30$ & ATTEND \\
\hline 20 & 120 & DICKY EFENDI & 03 August 2020 & $8: 00: 00$ & $9: 14: 30$ & ATTEND \\
\hline
\end{tabular}




\section{BEST}

Journal of Applied Electrical \& Science Technology - University of PGRI Adi Buana Surabaya

p-ISSN 2715-2871

e-ISSN 2714-5247

\section{Data Analysis}

After carrying out some tests as above, the writer can get some data, including the system can identify or recognize E-Ktp and RFID Reader tags, while the Mp3 DF Players work based on orders from the RFID Reader, if the RFID reads the E-KTP or RFID tag which is valid (registered) then the system will detect while if the RFID does not read the E-KTP or the invalid RFID tag (not registered) then the system and the LCD will display Unregistered.

\section{CONCLUSION}

Based on the analysis and research results in designing the attendance system tool for the Pilkades attendance system using the E-KTP Tap or RFID Tag based on the Nodemcu ESP8266 microcontroller, and based on the books related to the tool and the problems that arise during the design, several conclusions can be drawn as follows :

1. This series of RFID can be used as an attendance system for Pilkades participants to minimize cheating during general elections, and works well in accordance with E-KTP ID or RFID Tag ID as registered trial samples.

2. This series of RFID attendance systems is equipped with data export via Ms. Excel and via PDF to back up data so that any attendance data are not stuck with the web database system that is in the RFID attendance system.

Based on the results of the analysis and discussion in the previous analysis chapter, the following are suggestions for recommendations that can be given, including:

1. For the tools that the author made are less simple and less neat, therefore in the future this tool can be made that is simpler and more sophisticated with new developments.

3. For additions to the Face Recognition sensor and Fingerprint Sensor to be able to scan faces and fingerprints so that you can be more detailed in the future.

4. To be further developed in a less cooding system.

\section{REFERENCES}

[1] Alfien S, RS (2014). Student Attendance Application Using Fingerprints in Manado Public Senior High School 9. e-journal of Electrical and Computer Engineering.
[2] Dedy Cahyadi (2009) conducted a study entitled "Design of Civil Servant Attendance Systems based on RFID Technology".

[3] Finkenzeller, K. 2003. RFID Handbook: Fundamentals and application in contacless smart cards and identification, secon edition. West sussex: John wiley \& sons ltd.

[4] Govardhan .A and Ali Munassar .NM, 2010. A Comparison Between Five Models Of Software Engineering. IJCSI International Journal of Computer Science Issues, Vol. 7, hh. 94-101.

[5] Hamid (2010) in his research entitled "Parking Systems with RFID Technology as Unique Identifiers"

[6] Hasan A. Dkk., 2016. Student and Lecturer Attendance Recording System and Compensation Calculation in Telecommunication Engineering Study Program 74 Semarang State Polytechnic Using RFId. Techno, vol. 17, hh. 048

[7] Kristanto. A. 2008. Design of Information Systems and Applications. Yogyakarta: Gava Media Yogyakarta.

[8] Michael B. Jones., 2014. A JSON-Based Identity Protocol Suite. Information Standards Quarterly Fall vol 26, p. 19-22.

[9] Pradana, P. 2015. "Recording of hotel room access data with web-based rfid". Thesis. Sanata Dharma University

[10] Pressman, RS, 2010. Software Engineering A Practioner's Approach, McGrawHill. doi: 10.1109 / 6.476732.

[11] Qodri, Krisna Nuresa., 2017. Development of Token-Based UMY Student Attendance Applications. Yogyakarta: Muhammadiyah University of Yogyakarta.

[12] Tri Raharjo Yudantoro (2012) conducted a research entitled "Design of an RFID-based Library Book Theft Detection System"

[13] Yulianto, Ardhian Agung. Dkk., 2004. Analysis and Design of Information Systems.

[14] Sujiwa, Akbar, and Sagita Rochman. "Pengembangan Sistem Kontrol Serta Monitoring Suhu dan Volume Air Berbasis Web Pada Perangkat Desalinasi Air Laut." SNHRP (2019): 1-9. 